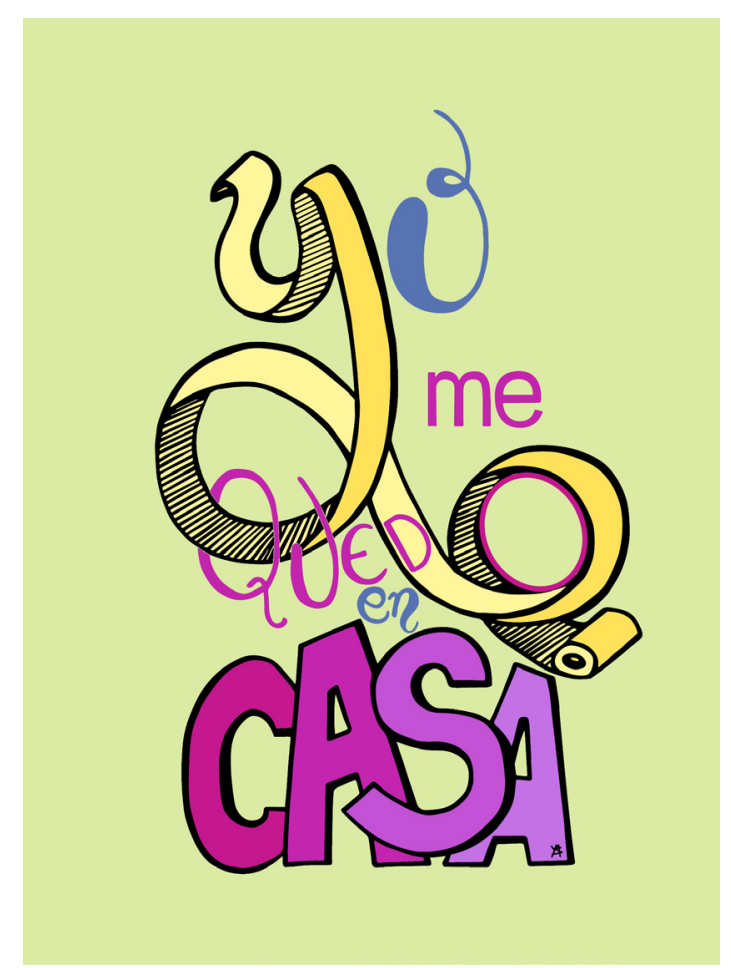

\title{
Yo me quedo en casa
}

\section{Reflexión}

Necesitaba liberar la sensación de angustia inicial por el COVID. Estaba bloqueada mental y emocionalmente, y coger el lápiz y el papel me ayudó a relajarme y a ordenar mis ideas de una forma increíble. Quería crear un mensaje que poner en mi ventana y en mis clases para transmitir esperanza mediante las formas y el color y responsabilidad con las palabras.

\section{Autora}

Begoña Yáñez Martínez. Doctora en Bellas Artes. Profesora de Composición y Tipografía en la Universidad Internacional de La Rioja. 